\title{
Designing public squares to optimize human outdoor thermal comfort: a case study in Safranbolu*
}

\author{
Ömer Özeren ${ }^{1}$ (1) Merve Tuna Kayılı² \\ 1 Lecturer, Karabük University, Faculty of Architecture, Department of Architecture, Karabük, TURKEY, e-mail: omerozeren@karabuk.edu.tr \\ 2 Assist. Dr., Karabük University, Faculty of Architecture, Department of Architecture, Karabük, TURKEY, e-mail: mervetunakayili@karabuk.edu.tr
}

\begin{abstract}
Within the scope of the study, thermal comfort analysis was performed using the ENVI-met program of the Misak-1 Milli Square in Safranbolu, and it was determined that the thermal comfort perception of the square as slighty warmwarm. For this reason, a new design proposal has been submitted for the square. In the proposal, the green ratio and the number of trees was increased, the type and location of the trees was changed. The flooring materials was replaced with a stone covering with a higher albedo and new functional suggestions were made for the square. As a result of the thermal comfort analysis of the new proposal, the thermal comfort perception in the square was neutral and the thermal dissatisfaction rate was reduced below $14.5 \%$. In result of the study, it was underlined that the ratio of green areas and the tree type, number and location that constitute it and the choice of flooring materials are important parameters in providing the thermal comfort of the square.
\end{abstract}

Keywords: Outdoor Thermal Comfort, Square, Green Ratio, Types of Trees, Flooring Material, Albedo

* This paper was presented as oral presentation in the International Sustainability Living Conference (ISLC 2020). 


\section{INTRODUCTION}

Cities are settlement units that meet the housing, rest and entertainment needs of the society. As a result of the high population growth in cities and the industrialization developing accordingly, the rate of green areas is gradually decreasing, and the remaining urban areas are not designed with sustainable design elements, resulting in thermal discomfort and heat islands. The squares, where city residents perform recreation (Dönmez et al.,2015), meeting and celebration activities, are the most important urban open spaces of the city (Öztürk, 2013). The thermal comfort of public squares in urban areas is particularly important. Many city dwellers use these squares regularly to spend leisure time or as a recreational area, especially during the summer season. Today, public squares are open to different uses such as recreation, sports and social activities and markets. Open spaces support active lifestyles, that is, social and cultural activities. Hence, it is a major responsibility for urban planners and researchers to analyze outdoor spaces and make them available to society (Kumar and Sharma, 2020).

In the absence of sufficient green areas in urban open areas, urban heat islands are formed. However, users of the square encounter an uncomfortable environment in terms of thermal comfort and have to reduce the usage time of the square. The Urban Heat Island (UHI) phenomenon is the high air and surface temperature that occurs in urban areas. UHI affects the quality of life in the outdoor environment and indoor conditions of the surrounding buildings (Mirzaei et al., 2012; Oke, 1982). The quality of life in the outdoor environment decreases with the decrease in outdoor thermal comfort. Besides thermal comfort, high temperatures cause health problems with concentrated pollutant concentrations and increase the cooling load of buildings (Aghamolaei et al., 2018; Li et al., 2018; Mirzaei, 2015). Urban areas with high population and building density are exposed to summer heat, which can have negative consequences on human health, especially fatigue, heart and respiratory ailments, and human psychology such as stress and anxiety (Johnson et al., 2012; Kovats and Hajat, 2008; Robine et al., 2008). Therefore, there is an urgent need for adaptation strategies to reduce the negative effects of heat on the urban population, both for the transformation of buildings and for the thermal comfort of the users (EEA, 2012).

Green ratio is the biggest factor in urban open areas, preventing heat islands and providing thermal comfort. Many studies confirm this opinion (De la Barrera and Henríquez, 2017; Duarte et al., 2015; Peña, 2009). Because the use of vegetation reduces events such as urban heat island and overheating and reduces the energy requirements for cooling in summer by reducing outdoor temperatures and solar radiation (Fabbri et al., 2020). In addition, in research on outdoor thermal comfort and design of public spaces, green area plays a key role in reducing solar radiation coming from the evapotranspiration event (Oke et al., 1989) and regulating the amount of water vapor in the air (Fabbri et al., 2020; Morakinyo and Lam, 2016; Müller et al., 2014). With a validated ENVImet model in a study conducted in Hong Kong, the current $7.2 \%$ green space and the proposed $30 \%$ green area thermal comfort were compared and the thermal comfort dissatisfaction determined as "very hot" was 17-21\% from 50\% (Morakinyo et al., 2018). Another study conducted in Cairo, which studied tree leaf sizes in addition to the percentage of green space, shows how much higher buildings and the lack of a plan for afforestation can increase problems associated with thermal stress (Fahmy et al., 2010)

It is supported by many studies that the form of the square, green ratio and tree species are effective parameters in increasing the outdoor heat comfort of urban open spaces (Simon et al., 2018; Zhang et al., 2018; Zölch, et al., 2016; Martins et al., 2016; Lobaccaro and Acero, 2015). Another factor in reducing urban heat islands is the use of highly reflective cold materials as flooring in the square. It can be said that high reflective floor coverings are another important parameter in providing thermal comfort in urban areas (Battista et al., 2016; Shahidan et al., 2012).

In this framework, within the scope of the study, it was aimed to improve the thermal comfort of the square with a new design proposal for Misak-I Milli Square with the awareness that the ratio of green areas tree species and high albedo coating material planned in urban areas, will improve the thermal comfort of the square. In this context, current thermal comfort analysis was made for the square. With the determination of insufficient thermal comfort and high thermal dissatisfaction, a new landscape design was proposed for the square. By conducting thermal comfort analyzes of the new proposal, the importance of green infrastructure and flooring materials on thermal comfort in square designs was highlighted. The study is expected to be a guide in terms of creating effective design principles in reducing thermal discomfort and heat islands seen in square designs. The flow of the study was given in Fig 1. 
Figure 1. Study Flow Diagram

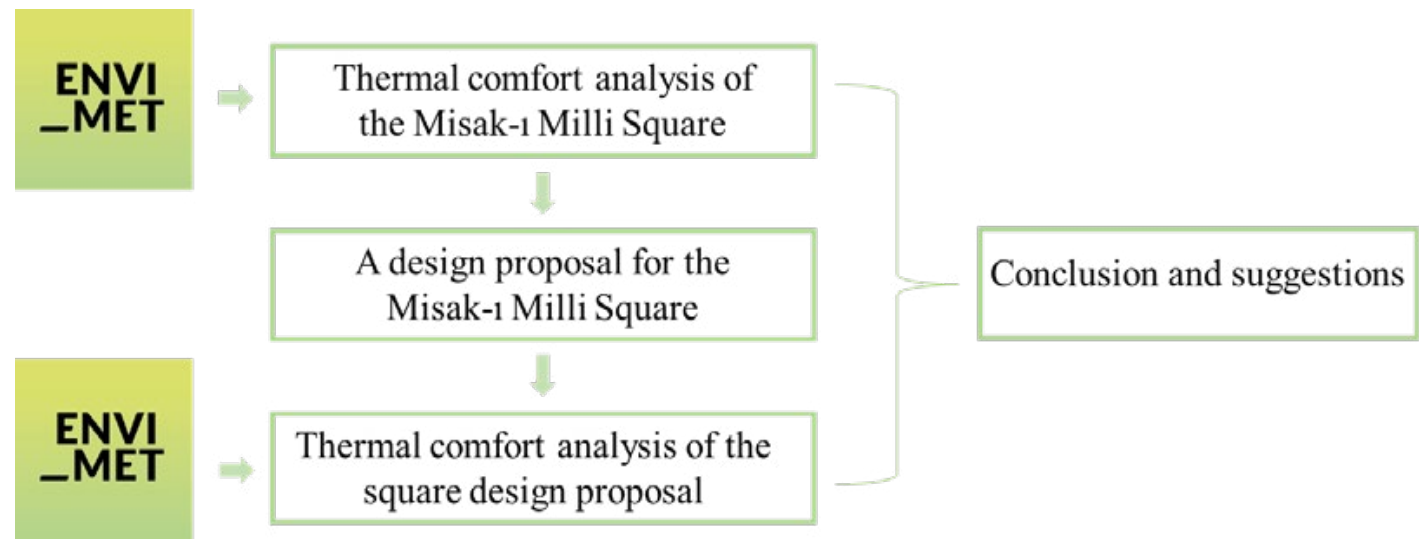

\section{METHODOLOGY}

In this section, the general and recreational characteristics of the Misak-1 Milli Square, the information about the ENVI-met program in which the analyzes were carried out and the principles and decisions in the new design proposal for the square are included.

\subsection{Misak-1 Milli Square}

The Misak-1 Milli Square, which is connected to Safranbolu Sadri Artunç Street and located in the center of the city (Fig 2a), stands out as an urban open area where individual activities such as resting and meeting of Safranbolu residents and social activities such as festival celebrations, fairs and concerts are held (Fig 3). The square is surrounded by approximately 5-6 storey buildings, and the rate of green detected in the square is around 3 percent (Fig 2b, Fig 3).

Figure 2: a) Satellite Image of Misak-1 Milli Square

b) Green Area (hatched area)

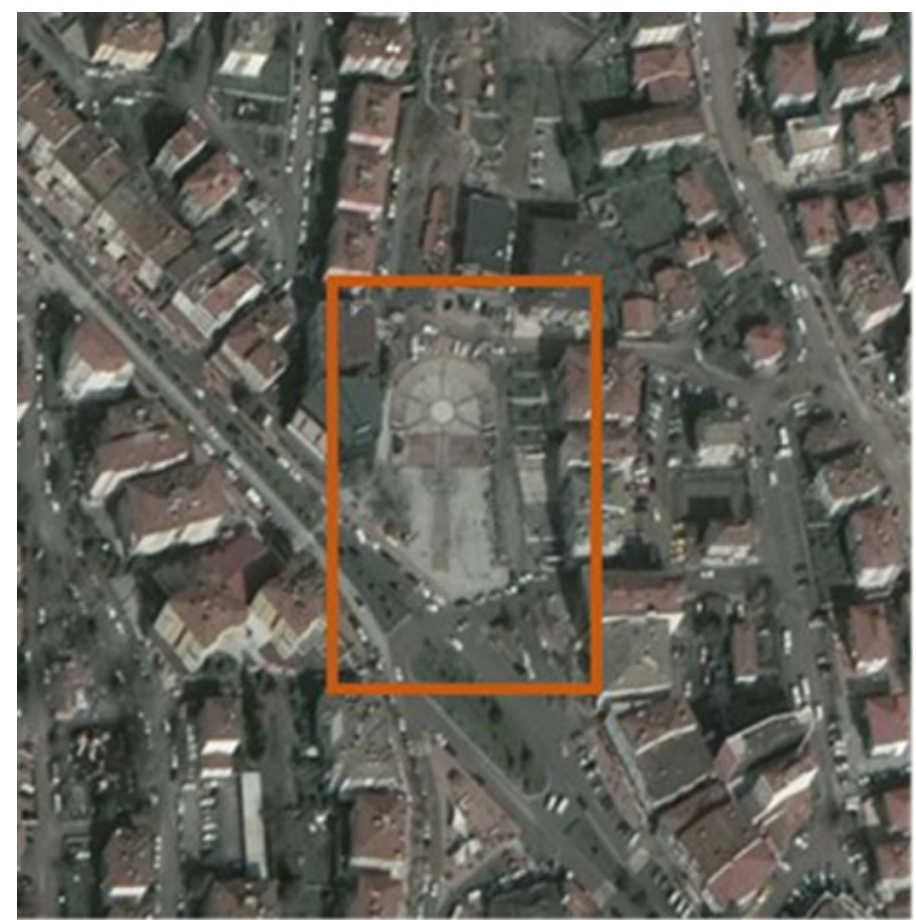

a

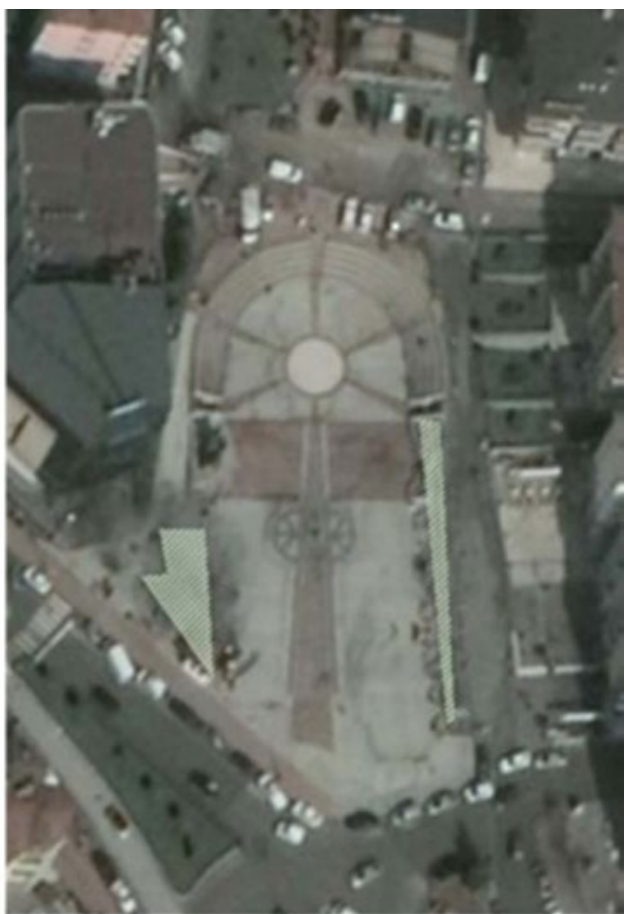

b 
Figure 3: Misak-1 Milli Square

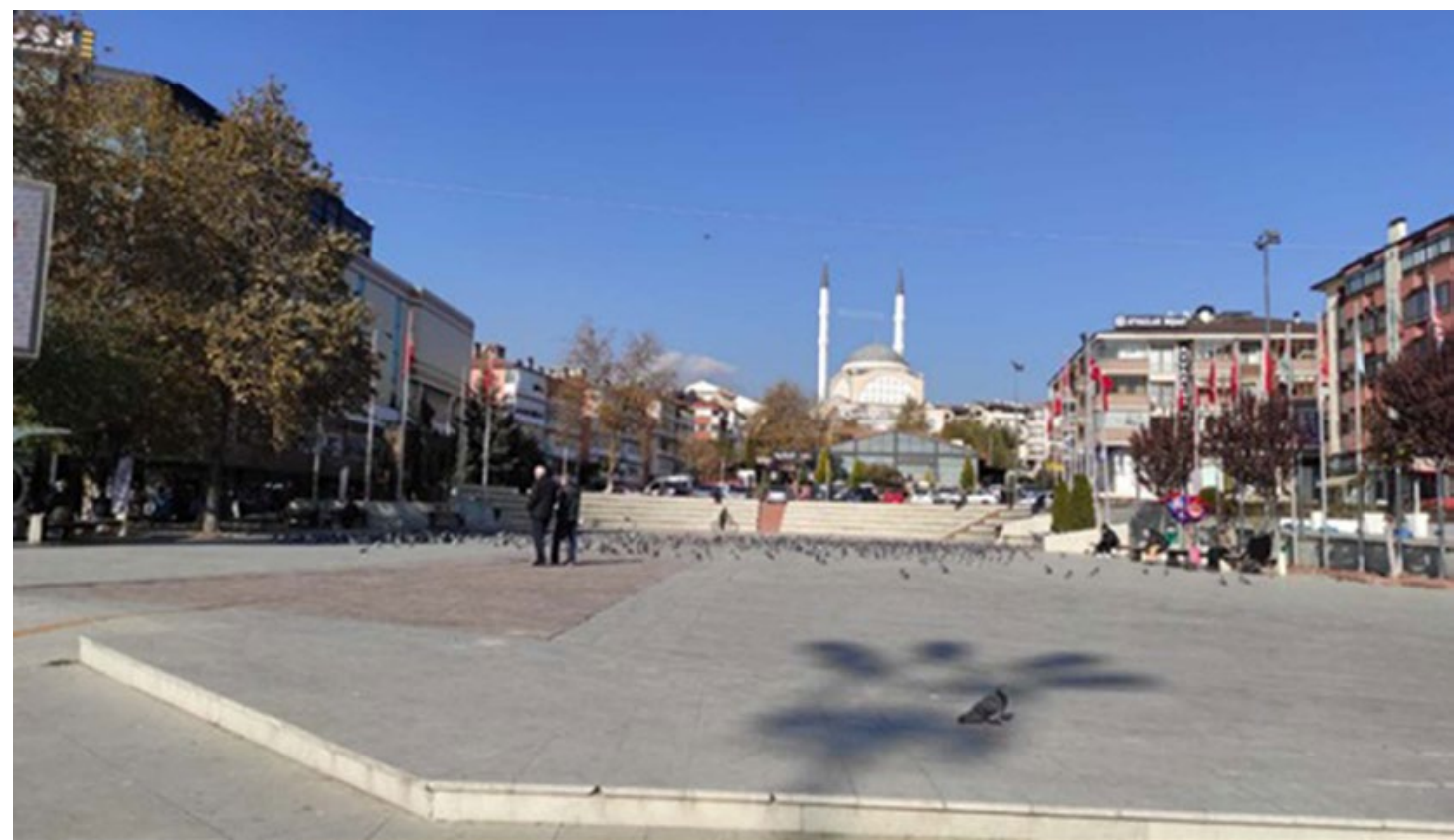

\subsection{ENVI-met Software}

The model background was defined by Bruse and Fleer, ENVI-met is a software that can simulate the microclimatic and physical behaviors of the outdoor space (Salata et al., 2016). Software It is one of the most widely used software when dealing with the impact of architectural structures and city planning on environmental variables and microclimate. In addition, the software stands out with its ability to provide values such as air temperature, average radiant temperature, wind speed, relative humidity, thermal comfort and discomfort percentage. This software has been used in many studies to evaluate urban settlement in terms of biometeorological conditions (Othmer et al., 2020; Salata et al., 2016; Lee et al., 2016; Martins et al., 2016; Tsilini et al., 2015; Johansson et al., 2014).

Model parameters must be entered in order to perform simulation with ENVI-Met 4.0 software (Bruse, 2004). These parameters are provided in 3 categories: field input file, configuration file and database. The field input file is created via a graphical interface and contains the geometric data of the simulated model. The configuration file shows the calculation parameters and conditions that characterize the simulation. The database contains data on vegetation cover and soil stratigraphy (Salata et al., 2016).

While the outdoor thermal comfort of Safranbolu Misak-1 Milli Square was simulated in the ENVI-met software, the climate data of Safranbolu were entered and the date of June 23, 2018 was selected for the summer period.

\subsection{Square Design Proposal and Design Principles}

When the current urban landscape design of Misak-1 Milli Square is examined, it is seen that it generally consists of hard ground and has a low green area ratio $(3 \%)$. This situation causes thermal comfort to decrease due to overheating of the square on hot days. It is observed that residents of the city avoid using this square, especially on hot days. However, the square and urban open spaces are defined not only as places for gathering, but also for recreation, entertainment and celebration activities. Ensuring the high usage of the square in the city is possible by providing thermal comfort and eliminating the heat island formation. For this reason, increasing the ratio of green areas, which is very low in the current design, is the basic design principle in the new design proposal. In the new design proposal for the square, the green ratio is planned as $21 \%$. The dominant wind direction of the square is southwest, and birch (Betula Pendula) trees, which can reach up to $30 \mathrm{~m}$ in height, are placed in the direction of the prevailing wind, and plain maples (Acer Campestre) and pine trees (Pinus Nigra), a type of maple, are placed in the other directions (Fig 4). The height and width of the Acer Campestre is $4 \mathrm{~m}$ and $3 \mathrm{~m}$, respectively. This dimension is $7 \mathrm{~m}$ and $5 \mathrm{~m}$ for Betula Pendula, and $12 \mathrm{~m}$ and $4 \mathrm{~m}$ for Pinus Nigra. 
The existing floor covering of the square is gray stone covering and the design proposal suggests a higher albedo, that is, a light colored stone covering. The properties of existing and recommended flooring materials are given in Table 1 . In addition, in order to increase the functionality of the square, the floor of the square was raised $3.5 \mathrm{~m}$ and arranged as an underground parking lot (Fig 5).

Figure 4: Square Design Proposal Tree Type and Layout Scheme

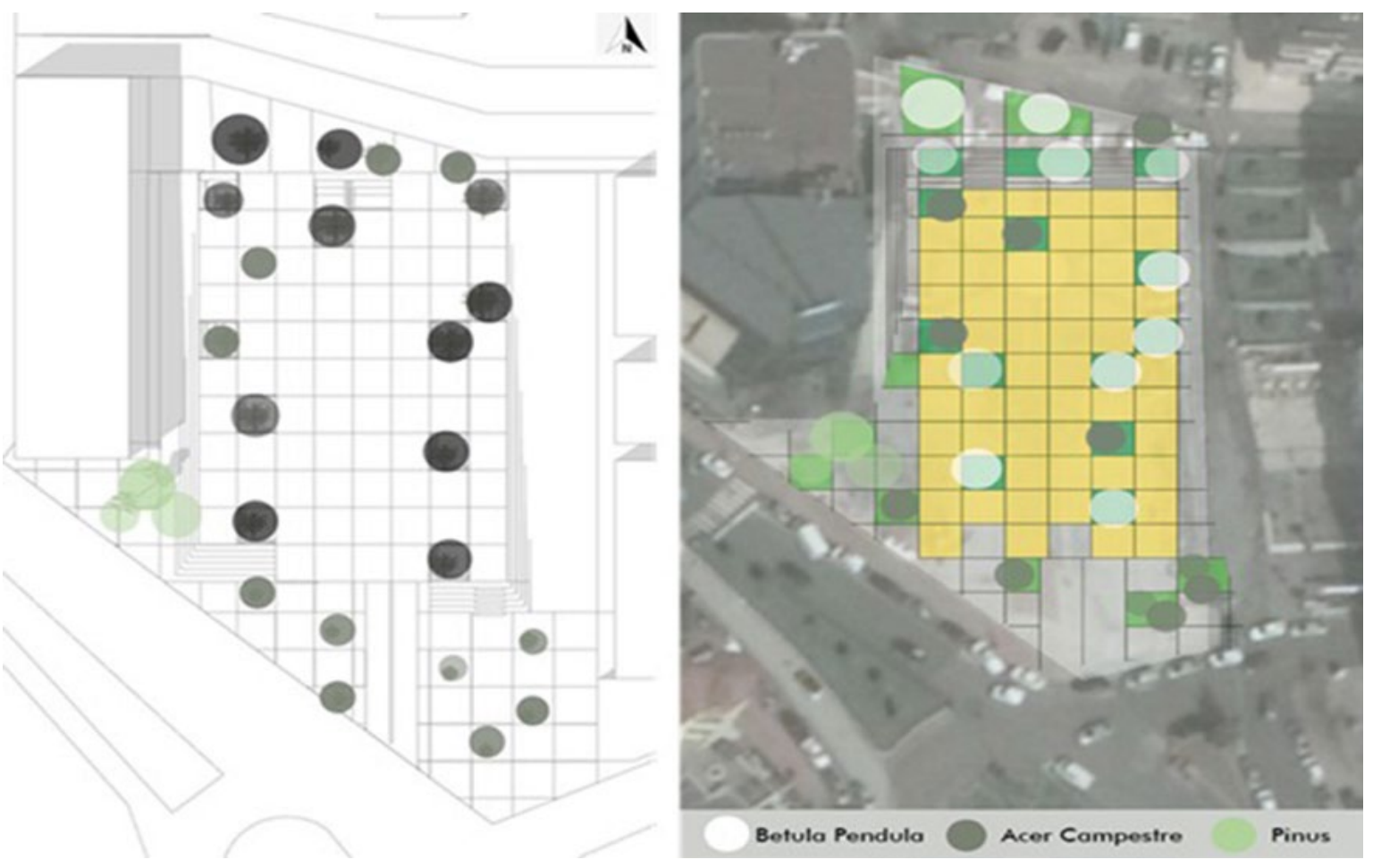

Table 1. Properties of the Flooring

\begin{tabular}{|l|l|l|l|}
\hline & z0 Roughness Lenght & Emissivity & Albedo \\
\hline Existing flooring (Gray stone) & 0.01 & 0.9 & 0.5 \\
\hline Suggestion flooring (Light gray stone) & 0.01 & 0.9 & 0.8 \\
\hline
\end{tabular}

Figure 5: Square Design Proposal

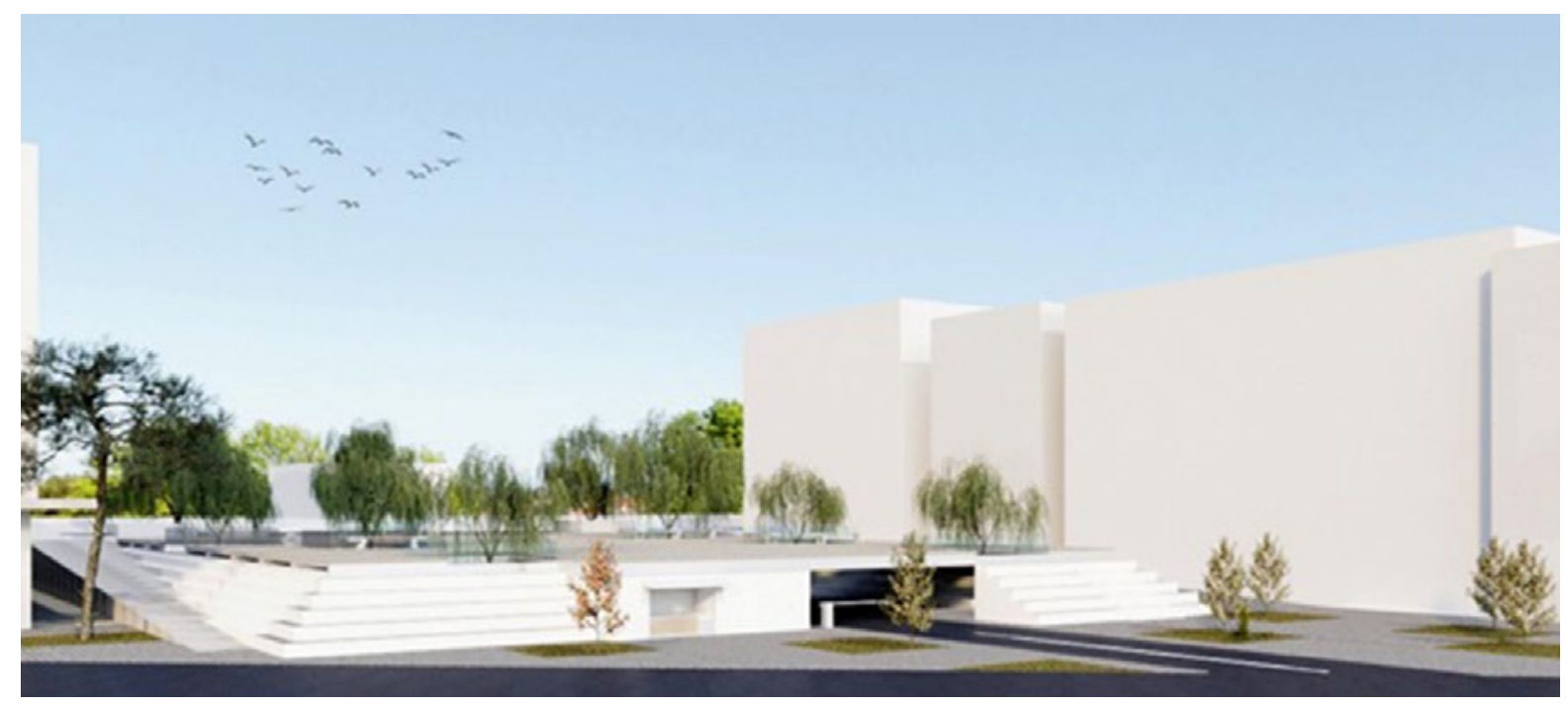




\section{RESULTS}

In this section, the thermal comfort analysis of the Misak-1 Milli Square and the thermal comfort analysis results of the proposed square design are included.

\subsection{Thermal Comfort of the Misak-1 Milli Square}

When the thermal comfort analysis obtained from the ENVI-met simulation program of the Misak-1 Milli Square is examined, the predicted mean vote (PMV), which indicates how the square users perceive the environment in terms of thermal comfort, is generally seen as 1-1.25. The thermal perception equivalent of this value is between slightly warmwarm. The values of 1.25-1.50 are seen in the parts of the square that are away from the green area. When the level of dissatisfaction of the users (PPD) with the thermal comfort level of the square is examined, the dissatisfaction rate of $33.50 \%$ to $43 \%$ in the part of the square where the recreational areas are located stands out (Fig 6).

Figure 6: PMV and PPD maps
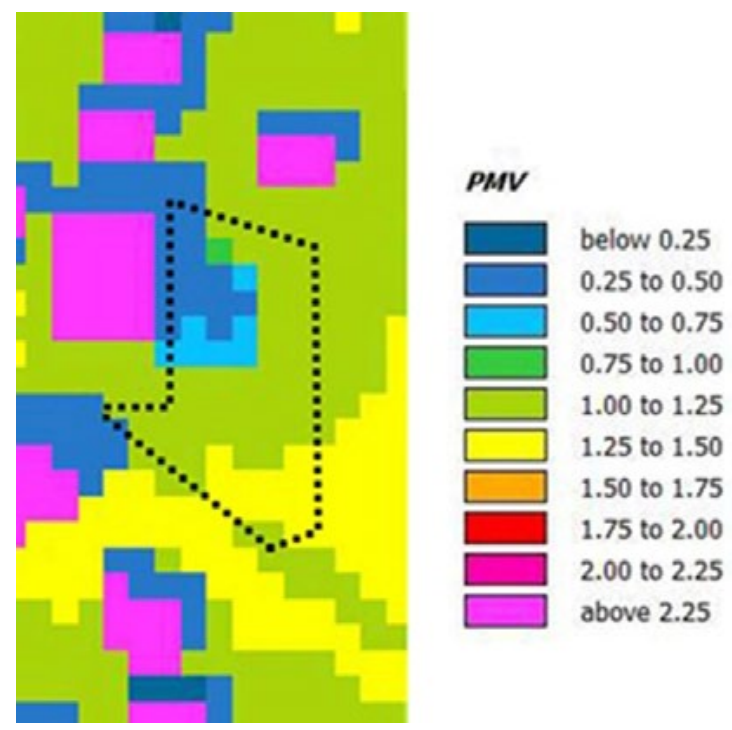

\subsection{Thermal Comfort of the Design Proposal for the} Misak-1 Milli Square

When the thermal comfort value of the design proposal planned for Misak National Square is examined, the PMV value is in the range of $0.25-0.50$, and the thermal perception equivalent of this range is neutral. At this comfort level, the level of dissatisfaction (PPD) of the users with the thermal comfort level of the square falls below $14.50 \%$ and it can be said that the dissatisfaction rate is very low. In improving thermal comfort, increasing the percentage of green area of the square (Kong et al., 2016; Fabbri et al., 2020), increasing the

below $14.50 \%$ 14.50 to $24.00 \%$ 24.00 to $33.50 \%$ 33.50 to $43.00 \%$ 43.00 to $52.50 \%$ 52.50 to $62.00 \%$ 62.00 to $71.50 \%$ 71.50 to $81.00 \%$ 81.00 to $90.50 \%$ above $90.50 \%$ number of trees and changing their species (de AbreuHarbich et al. 2015) and location (Klemm et al., 2017; Coutts et al., 2016), suggesting a material with a lower albedo value for the flooring material (Battista et al., 2016; Shahidan et al., 2012). Studies on this subject indicate that these recommendations are important parameters that are effective in increasing thermal comfort and reducing heat islands. 
Figure 7: PMV and PPD Maps for Proposal
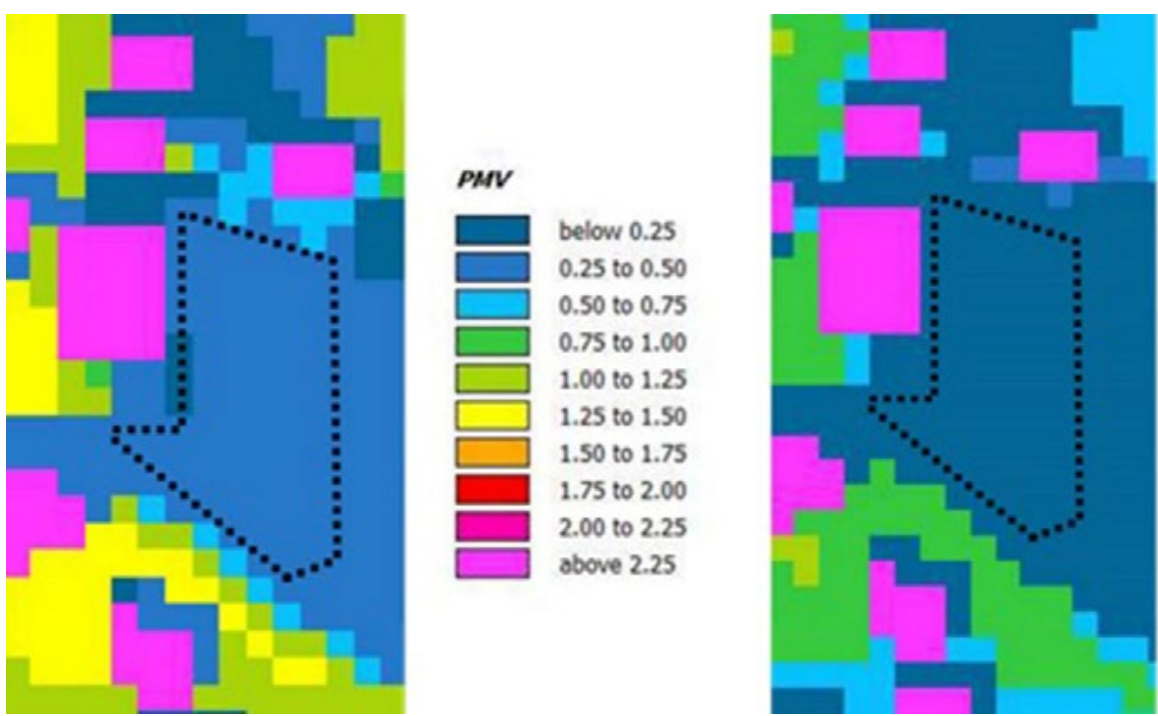

$P P D$

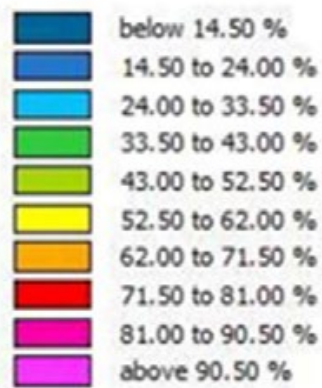

\section{CONCLUSION AND SUGGESTIONS}

Within the scope of the study, the thermal comfort analysis of the Misak-1 Milli Square was performed and it was determined that the thermal discomfort was high. In this context, a new design proposal has been made for the square. In the design proposal, the existing green area percentage was increased from $3 \%$ to $21 \%$ and the number of trees was increased. Different wood species were placed according to the prevailing wind direction and other directions, and the flooring material was replaced with a material with a higher albedo value. In the context of these suggestions, with the thermal comfort analysis of the design proposal, it has been determined that the thermal perception of the square will be neutral and the dissatisfaction rate will fall below $14.5 \%$ from $43 \%$. The results show that some important issues should be taken into account before planning a climate-adapted and thermally comfortable square (Zölch, et al., 2016). It can be said that the most important factor during the day is the shading that can be improved by placing additional trees in the sunny areas of the square. During the night, natural ventilation is the most important factor that allows air to pass through the square and distribute warm air from under the treetops. Therefore, landscape architects or designers should determine the dominant wind channel and direction in the square and leave this area open. It is recommended to locate treeless green areas in these areas. In squares in hot climates, high green areas and afforestation rates, shading elements and floor coverings with high albedo values can be considered as important design principles to ensure thermal comfort. Achieving these principles is possible with the square designers making their design decisions based on climatic data. It is also important that these principles are taken into account by local governments.

In today's world, where migration from rural to urban is increasing, the provision of thermal conditions in the squares surrounded by high-rise buildings to meet the housing needs of the high population will be even more important in the future. In order for urban open spaces, which are the only places where people can breathe in cities, to become thermally comfortable spaces, the research is planned to focus on changing the square geometry with more tree species in the next stage.

\section{REFERENCES}

- AGHAMOlAEI, R., SHAMSI, M. H., TAHSILDOOST, M. \& O'DONNELL, J. (2018). Review of District-Scale Energy Performance Analysis: Outlooks Towards Holistic Urban Frameworks. Sustainable Cities and Society. 41, 252-264.

- BATtista, G., CARNiElO, E. \& VOllaRO, R. D. L. (2016). Thermal Impact of A Redeveloped Area on Localized Urban Microclimate: A Case Study in Rome. Energy and Buildings. 133, 446-454.

- BRUSE, M. (2004). ENVI-met 3.0: Updated Model Overview. University of Bochum. Retrieved from: www.envi-met. com.

- COUTTS, A. M., WHITE, E. C., TAPPER, N. J., BERINGER, J. \& LIVESLEY, S. J. (2016). Temperature and Human Thermal Comfort Effects of Street Trees Across Three Contrasting Street Canyon Environments. Theoretical and Applied Climatology, 124(1-2), 55-68. DOI 10.1007/ s00704-015-1409-y 
- DE ABREU-HARBICH, L. V., LABAKI, L. C. \& MATZARAKIS, A. (2015). Effect Of Tree Planting Design And Tree Species on Human Thermal Comfort in The Tropics. Landscape and Urban Planning, 138, 99-109.

- DE LA BARRERA, F. \& HENRÍQUEZ, C. (2017). Vegetation Cover Change in Growing Urban Agglomerations in Chile. Ecol. Indic. 81, 265-273.

- DÖNMEZ, Y, ÖZYAVUZ, M. \& GÖKYER, E. (2015). Safranbolu Kentinin Konut ve Site Alanlarının Yeşil Alan Durumlarının Saptanması. İnönü Üniversitesi Sanat ve Tasarım Dergisi, 5(11), $1-12$.

- DUARTE, D. H., SHINZATO, P., DOS SANTOS GUSSON, C. \& ALVES, C. A. (2015). The Impact of Vegetation on Urban Microclimate to Counterbalance Built Density in A Subtropical Changing Climate. Urban Climate, 14, 224-239.

- EUROPEAN ENVIRONMENTAL AGENCY (EEA), Urban Adaptation to Climate Change in Europe - Challenges and Opportunities for Cities Together with Supportive National and European Policies, (2012) Retrieved from http:/ / www.eea.europa. eu / publications / urban-adaptation-to-climate-change(Access Date: $21 / 10 / 2020)$

- FABBri, K., UGOLINI, A., IACOVEllA, A. \& BIANCHI, A. P. (2020). The Effect Of Vegetation in Outdoor Thermal Comfort in Archaeological Area in Urban Context. Building and Environment, 106816.

- FAHMY, M., SHARPLES, S. \& YAHIYA, M. (2010). LAI Based Trees Selection for Mid Latitude Urban Developments: A Microclimatic Study in Cairo, Egypt. Building and Environment, 45(2), 345-357.

- JOHANSSON, E., THORSSON, S., EMMANUEL, R. \& KRÜGER, E. (2014). Instruments and Methods in Outdoor Thermal Comfort Studies-The Need For Standardization. Urban Climate, 10, 346-366.

- JOHNSON, D. P., STANFORTH, A., LULLA, V. \& LUBER, G. (2012). Developing an Applied Extreme Heat Vulnerability Index Utilizing Socioeconomic And Environmental Data. Applied Geography, 35(12), 23-31.

- KLEMM, W., LENZHOLZER, S. \& VAN DEN BRINK, A. (2017). Developing Green Infrastructure Design Guidelines for Urban Climate Adaptation. Journal of Landscape Architecture, 12(3), 60-71.

- KONG, F., SUN, C., LIU, F., YIN, H., JIANG, F., PU, Y., CAVAN, G., SKELHORN, C., MIDDEL, A. \& DRONOVA, I. (2016). Energy Saving Potential of Fragmented Green Spaces Due to Their Temperature Regulating Ecosystem Services in The Summer. Applied Energy, 183, 1428-1440.

- KOVATS, R. S. \& HAJAT, S. (2008). Heat Stress and Public Health: a Critical Review. Annu. Rev. Public Health, 29, 41-55.

- KUMAR, P. \& SHARMA, A. (2020). Study on Importance, Procedure, and Scope of Outdoor Thermal Comfort-A Review. Sustainable Cities and Society, 102297.

- LEE, H., MAYER, H. \& CHEN, L. (2016). Contribution of Trees and Grasslands to the Mitigation of Human Heat Stress in a Residential District of Freiburg, Southwest Germany. Landscape and Urban Planning, 148, 37-50.

- LI, G., ZHANG, X., MIRZAEI, P. A., ZHANG, J. \& ZHAO, Z. (2018). Urban Heat Island Effect of A Typical Valley City in China: Responds to The Global Warming and Rapid Urbanization. Sustainable Cities and Society, 38, 736-745

- LOBACCARO, G. \& ACERO, J. A. (2015). Comparative Analysis of Green Actions to Improve Outdoor Thermal Comfort Inside Typical Urban Street Canyons. Urban Climate, 14, 251-267.

- MARTINS, T. A., ADOLPHE, L., BONHOMME, M., BONNEAUD, F., FARAUT, S., GINESTET, S., MICHELL, C. \& GUYARD, W. (2016). Impact of Urban Cool Island Measures on Outdoor Climate and Pedestrian Comfort: Simulations for a New District of Toulouse, France. Sustainable Cities and Society, 26, 9-26.
- MIRZAEI, P. A. (2015). Recent Challenges in Modeling of Urban Heat Island. Sustainable Cities and Society, 19, 200-206.

- MIRZAEI, P. A., HAGHIGHAT, F., NAKHAIE, A. A., YAGOUTI, A., GIGUÈRE, M., KEUSSEYAN, R. \& COMAN, A. (2012). Indoor Thermal Condition in Urban Heat Island-Development of A Predictive Tool. Building and Environment, 57, 7-17.

- MORAKINYO, T. E. \& LAM, Y. F. (2016). Simulation Study on The Impact Of Tree-Configuration, Planting Pattern and Wind Condition on Street-Canyon's Micro-Climate and Thermal Comfort. Building and Environment, 103, 262-275.

- MORAKINYO, T. E., LAU, K. K. L., REN, C. \& NG, E. (2018). Performance of Hong Kong's Common Trees Species for Outdoor Temperature Regulation, Thermal Comfort and Energy Saving. Building and Environment, 137, 157-170.

- MÜLLER, N., KUTTLER, W. \& BARLAG, A. B. (2014). Counteracting Urban Climate Change: Adaptation Measures and Their Effect On Thermal Comfort. Theoretical and Applied Climatology, 115(1-2), 243257.

- OKE, T. R. (1982). The Energetic Basis of The Urban Heat Island. Quarterly Journal of the Royal Meteorological Society, 108(455), $1-24$.

- OKE, T.R., CROWTHER, J.M., MCNAUGHTON, K.G., MONTEITH, J.L. \& GARDINER, B. (1989). The micrometeorology of the urban forest [and discussion], Philos. Trans. R. Soc. London B Biol. Sci. 324 335-349.

- OTHMER, F. J., SCHMITT, J. P. \& GREIVING, S. (2020). Numerical Modelling of The Urban Climate as an Integrated Part of Environmental Assessments. Science of The Total Environment, 731, 138774.

- ÖZTÜRK, S. (2013). Kentsel Açık ve Yeşil Alanların Yaşam Kalitesine Etkisi. Kastamonu Örneği. Kastamonu Üniversitesi Orman Fakültesi Dergisi, 13(1), 109-116.

- PEÑA, M. (2009). Examination of the Land Surface Temperature Response for Santiago, Chile. Photogramm. Eng. Remote. Sens. 75 (10), 1191-1200.

- ROBINE, J. M., CHEUNG, S. L. K., LE ROY, S., VAN OYEN, H., GRIFFITHS, C., MICHEL, J. P. \& HERRMANN, F. R. (2008). Death toll exceeded 70,000 in Europe during the summer of 2003. Comptes Rendus Biologies, 331(2), 171-178.

- SAlATA, F., GOLASI, I., DE LIETO VOlLARO, R. \& DE LIETO VOLLARO, A. (2016). Urban Microclimate and Outdoor Thermal Comfort. A Proper Procedure to Fit ENVI-Met Simulation Outputs to Experimental Data. Sustainable Cities and Society, 26, 318-343.

- SHAHIDAN, M. F., JONES, P. J., GWILLIAM, J. \& SALLEH, E. (2012). An Evaluation of Outdoor and Building Environment Cooling Achieved Through Combination Modification of Trees with Ground Materials. Building and Environment, 58, 245-257.

- SIMON, H., LINDÉN, J., HOFFMANN, D., BRAUN, P., BRUSE, M. \& ESPER, J. (2018). Modeling Transpiration and Leaf Temperature of Urban Trees-A Case Study Evaluating The Microclimate Model ENVI-met Against Measurement Data. Landscape and Urban Planning, 174, 33-40.

- TSILINI, V., PAPANTONIOU, S., KOLOKOTSA, D. D. \& MARIA, E. A. (2015). Urban Gardens as a Solution to Energy Poverty and Urban Heat Island. Sustainable Cities and Society, 14, 323-333.

- ZHANG, L., ZHAN, Q. \& LAN, Y. (2018). Effects of The Tree Distribution and Species on Outdoor Environment Conditions in a Hot Summer and Cold Winter Zone: A Case Study in Wuhan Residential Quarters. Building and Environment, 130, 27-39.

- ZÖLCH, T., MADERSPACHER, J., WAMSLER, C. \& PAULEIT, S. (2016). Using Green Infrastructure for Urban Climate-Proofing: An Evaluation of Heat Mitigation Measures at The Micro-Scale. Urban Forestry \& Urban Greening, 20, 305-316. 